\title{
Long-term increase of insulin secretion in mice subjected to pregnancy and lactation
}

\author{
Julia Modesto Vicente' ${ }^{1}$ Junia Carolina Santos-Silva', Caio Jordão Teixeira', Dailson Nogueira de Souza', \\ Jean Franciesco Vettorazzi ${ }^{2}$, Fabiola Sales Furtuoso', Isabel Gouveia Adabo ${ }^{1}$, Fabio Takeo Sato ${ }^{3}$, \\ Marco Aurélio Ramirez Vinolo ${ }^{3}$, Everardo Magalhães Carneiro ${ }^{2}$, Silvana Bordin ${ }^{4}$ and Gabriel Forato Anhê ${ }^{1}$ \\ ${ }^{1}$ Department of Pharmacology, Faculty of Medical Sciences, State University of Campinas, Campinas, Brazil \\ ${ }^{2}$ Department of Structural and Functional Biology, Institute of Biology, State University of Campinas, Campinas, Brazil \\ ${ }^{3}$ Department of Genetics, Evolution, Microbiology and Immunology, Institute of Biology, State University of Campinas, Campinas, Brazil \\ ${ }^{4}$ Department of Physiology and Biophysics, Institute of Biomedical Sciences, University of Sao Paulo, Sao Paulo, Brazil \\ Correspondence should be addressed to G F Anhe: anhegf@fcm.unicamp.br
}

\begin{abstract}
Purpose: Observational studies show that longer breastfeeding periods reduce maternal risk of type 2 diabetes mellitus. However, it is currently unknown if the long-term benefits of breastfeeding for maternal glucose homeostasis are linked to changes in the endocrine pancreas.

Methods: We presently evaluated functional, morphological and molecular aspects of the endocrine pancreas of mice subjected to two sequential cycles of pregnancy and lactation (L21). Age-matched mice not allowed to breastfeed (LO) and virgin mice were used as controls.

Results: L21 mice exhibited increased tolerance and increased glucose-stimulated insulin secretion (GSIS) by isolated islets. Pancreatic islets of L21 mice did not present evident morphological changes to justify the increased GSIS. On the other hand, islets of L21 mice exhibited a reduction in Cavb3 and Kir6.2 expression with concordant increased intracellular $\mathrm{Ca}^{2+}$ levels after challenge with glucose.

Conclusion: Altogether, the present findings show the breastfeeding exerts long-term benefits for maternal endocrine pancreas by increasing intracellular $\mathrm{Ca}^{2+}$ levels and GSIS.
\end{abstract}
Key Words
- pregnancy
- lactation
pancreatic islets
- insulin secretion
- type 2 diabetes mellitus

\section{Introduction}

The benefits of breastfeeding for infant health are solidly supported by a great number of studies. Since the first observational study showing reduced mortality rate in breastfed infants compared to bottle-fed infants (1), many investigations have further detailed the hazards arising from insufficient or absent breastfeeding to the newborn. Infants subjected to inadequate breastfeeding have higher rates of infectious morbidity, including otitis media, gastroenteritis and pneumonia (2). Adolescents exposed to shorter breastfeeding periods are also more prone to develop metabolic syndrome and type 2 diabetes mellitus (T2DM) $(3,4,5)$.
More recently, epidemiological studies have also detailed a wide range of benefits that breastfeeding yields to mothers later in life (2). Retrospective cohort studies have demonstrated that short periods of breastfeeding are directly associated with higher risk for T2DM in young and middle-aged mothers with no history gestational diabetes $(6,7)$. Additional prospective data revealed that exclusive breastfeeding for at least 6 months presented increased insulin sensitivity as assessed by HOMA-IR index 3 years after delivery rather than increased pancreatic $\beta$-cell function as indicated by in vivo insulin secretion (8).

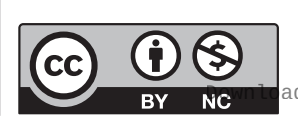

This work is licensed under a Creative Commons Attribution-NonCommercial 4.0 International License. ded from Bioscientifica.com at 04/26/2023 09:24:40AM 
Experimental studies on this topic are rare but somehow concordant with the observational data. Female mice subjected to a history of pregnancy and lactation were described to maintain reduced glycaemia 6 months after delivery (9). On the other hand, rats exposed to subsequent cycles of pregnancy without lactation exhibited increased glucose levels at the 20th gestational day when compared to age-matched virgin rats (10).

Apart from these studies, no investigation has elucidated if the history of pregnancy with or without lactation can affect maternal pancreatic islet physiology later in life. To address this issue, we have assessed in vivo glucose homeostasis and morphological and functional aspects of islets isolated from mice subjected to a history of pregnancy with or without lactation. Other parameters such as intracellular calcium dynamics and the expression of genes that are pivotal for pancreatic islets physiology have also been evaluated.

\section{Materials and methods}

\section{Experimental design}

All experimental procedures were conducted with the approval of the Committee for Ethics in Animal Experimentation at the State University of Campinas (protocol n. 4385-1). Female and male C57BL/6J mice were purchased from Animal Breeding Center at the University of Campinas (CEMIB, Campinas, Sao Paulo, Brazil) and housed at $22 \pm 2^{\circ} \mathrm{C}$ under a 12-h light-dark cycle (lights 07:00-19:00h), with free access to food (Nutrilab, Colombo, Paraná, Brazil) and water.

The protocols for mating, assignment into the different groups and litter adjustment were performed as previously described (11). Briefly, 9-week-old female mice were continuously housed for 5 days with males of the same age (two females: one male). Age-matched mice were kept unmated to be assigned to the Virgin group. Pregnant mice were either allowed to breastfeed for 21 days (L21) or had the litter removed no longer than $24 \mathrm{~h}$ after delivery (L0). L21 and L0 mice were subjected to two cycles of pregnancy. The second mating occurred 5 weeks after the first delivery. The experiments were performed 3 months after the second delivery. The age-matched virgin mice were subjected to identical housing conditions. The mean success of pregnancy in the first mating was $70 \%$, and the mean success of pregnancy in the second mating was $74 \%$.
Intraperitoneal glucose (ipGTT) and insulin tolerance test (ipITT)

Animals were submitted to overnight fasting and blood glucose was measured (time 0). For ipGTT, a glucose load of $2 \mathrm{~g} / \mathrm{kg}$ of body weight was then administered by i.p. injection, and additional blood samples were collected at 15, 30, 60, 90 and $120 \mathrm{~min}$ to measure glycemia. For the ipITT, $1 \mathrm{U} / \mathrm{kg}$ of body weight of human insulin (Lilly) was administered by i.p. injection, and additional blood samples were collected at 5, 10, 15, 20, 25 and $30 \mathrm{~min}$ for blood glucose measurements. The area under the curve (AUC) of glycemia vs time was calculated above each individual baseline (basal glycemia) to estimate glucose tolerance at the ipGTT. The constant rate of glucose disappearance $\left(\mathrm{K}_{\text {ITT }}\right)$ was calculated using the formula $0.693 /$ half-life. The glucose half-life was calculated from the slope of the least-squares analysis of the blood glucose concentrations during the linear phase of decay.

\section{Flow cytometry}

Retroperitoneal and inguinal adipose fat pads were weighted, minced with scissors and incubated in medium containing collagenase (DMEM, $\mathrm{NaHCO}_{3}, \mathrm{HEPES}$, BSA and $0.8 \%$ of type IA collagenase from Sigma-Aldrich, $\mathrm{pH}$ adjusted to 7.5$)$ at $37^{\circ} \mathrm{C}$, under agitation $(110 \mathrm{rpm})$ in an orbital shaker for $45 \mathrm{~min}$. Macrophages were filtered in cell strainer $(100 \mu \mathrm{m})$ and washed three times with DMEM medium without collagenase. Erythrocytes were removed using hemolysis buffer. After removal of the lysis buffer, cells were resuspended in $2 \mathrm{~mL}$ of FACS buffer and were counted in Neubauer chamber.

Cell suspension $\left(1 \times 10^{6}\right)$ was preincubated with Fc block (anti-CD16/CD32; Thermo Fisher) at $4^{\circ} \mathrm{C}$ for $5 \mathrm{~min}$ and then stained with the following antibodies: antiCD11c-PE, anti-CD206-APC and anti-F4/80-APC/Cy7 (all from Biolegend, San Diego, CA, USA). Samples were incubated for $30-60 \mathrm{~min}$ at $4^{\circ} \mathrm{C}$ in the dark. Cells were then centrifuged $\left(140 \mathrm{~g}, 5 \mathrm{~min}, 4^{\circ} \mathrm{C}\right)$, the supernatant discarded, and the cells were washed with FACS buffer. Cells were suspended in $200 \mu \mathrm{L}$ of FACS buffer and then analyzed in flow cytometer (FACSVerse, BD Biosciences). The analyses were performed using FlowJo v. 9.0 with the gating strategy shown in Fig. 3A. Fat pad weights were expressed as the percentage of body weight (Table 1).

\section{Pancreatic islet isolation and insulin secretion}

Islets were isolated after the perfusion and digestion of the pancreas with collagenase, as described before (12). After

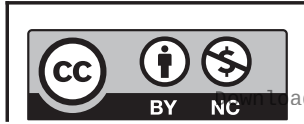

This work is licensed under a Creative Commons Attribution-NonCommercial 4.0 International License. ded from Bioscientifica.com at 04/26/2023 09:24:40AM 
Table 1 Adiposity and pancreas morphometric data of Virgin, L0 and L21 mice.

\begin{tabular}{l}
\hline \\
\hline Inguinal fat pad (\% of body weight) \\
Retroperitoneal fat pad (\% of body weight) \\
Pancreas weight (mg) \\
Pancreatic islet mass (mg) \\
Pancreatic $\beta$-cell mass (mg) \\
Pancreatic non- $\beta$-cell mass (mg) \\
Number of islets per pancreas section
\end{tabular}

\begin{tabular}{c}
\hline Virgin \\
\hline $1.2 \pm 0.2(9)$ \\
$0.6 \pm 0.05(9)$ \\
$327 \pm 38.5(4)$ \\
$2.36 \pm 0.9(4)$ \\
$1.65 \pm 0.7(4)$ \\
$0.76 \pm 0.3(4)$ \\
$55 \pm 6(4)$ \\
\hline
\end{tabular}

\begin{tabular}{c}
\hline L0 \\
\hline $1.5 \pm 0.3(10)$ \\
$1.1 \pm 0.3(10)$ \\
$397 \pm 54.9(4)$ \\
$4.04 \pm 0.8(4)$ \\
$3.07 \pm 0.6(4)$ \\
$1.04 \pm 0.2(4)$ \\
$72 \pm 11(4)$ \\
\hline
\end{tabular}

\begin{tabular}{c}
\hline $\mathbf{L 2 1}$ \\
\hline $1.2 \pm 0.3(7)$ \\
$0.7 \pm 0.08(7)$ \\
$313 \pm 22.5(4)$ \\
$2.22 \pm 0.3(4)$ \\
$1.60 \pm 0.2(4)$ \\
$0.63 \pm 0.04(4)$ \\
$92 \pm 9(4)$
\end{tabular}

Data are presented as the mean \pm S.E.M.. Retroperitoneal adiposity, the masses of pancreatic islet, pancreatic $\beta$-cell and pancreatic non- $\beta$-cell, and the number of islets per pancreas section were compared using Kruskal-Wallis test. The pancreas weight and the inguinal adiposity were compared with one-way ANOVA. The numbers of independent measures are in parenthesis.

isolation and manual separation from the exocrine tissue, groups of five islets were incubated for $30 \mathrm{~min}$ at $37^{\circ} \mathrm{C}$ in Krebs-Ringer bicarbonate (KRB) buffer containing $115 \mathrm{mM}$ $\mathrm{NaCl}, 5 \mathrm{mM} \mathrm{KCl}, 10 \mathrm{mM} \mathrm{NaHCO}, 2.56 \mathrm{mM} \mathrm{CaCl}_{2}, 1 \mathrm{mM}$ $\mathrm{MgCl}_{2}$ and $15 \mathrm{mM}$ HEPES, pH 7.4, supplemented with $5.6 \mathrm{mM}$ glucose plus $0.3 \% \mathrm{BSA}$ (Sigma Chemical). After this 30-min period of pre-incubation, the islets were incubated with a fresh KRB buffer with different glucose concentrations for $1 \mathrm{~h}$ at $37^{\circ} \mathrm{C}$. The cumulative insulin release over $1 \mathrm{~h}$ was quantified in duplicate using commercial ELISA kit (Cat No. EZRMI-13K, Merck Millipore).

\section{Immunohistochemistry and pancreas morphology}

The whole pancreas was removed, weighted, fixed in fixative solution and embedded in paraffin. The sections obtaining, insulin staining for immunohistochemistry and pancreatic morphometry were performed as previously described (13). Briefly, two sections of each pancreas were randomly selected for analysis of endocrine pancreas morphology. All islets present in the sections were covered systematically by capturing images with a digital camera (Olympus DP72) coupled to an Olympus BX51TF microscope. The pancreatic islet area was obtained by manual areas were obtained by manual tracing of insulinpositive and insulin-negative cells from all islets on the sections. Images analysis was performed with ImageJ software (http://imagej.nih.gov/ij) tracing of all islets on the sections. The islet, $\beta$-cell and non- $\beta$-cell masses (mg) were determined by multiplying their respective relative mass (obtained by the sum of the islet, $\beta$-cell or non- $\beta$-cell areas corrected by the total area of the pancreas section) by the pancreas mass.

\section{Cytoplasmatic $\mathrm{Ca}^{2+}$ dynamics}

Islets were processed for evaluation of cytoplasmatic $\mathrm{Ca}^{2+}$ as previously described $(14,15)$. Briefly, after loading with Fura-2 acetoxymethylesther, the islets were perfused with albumin-free KRB-buffer ( $\mathrm{pH}$ 7.4) containing either $5.6 \mathrm{mM}$ or $11.1 \mathrm{mM}$ glucose, as indicated in the figures. Changes in intracellular $\mathrm{Ca}^{2+}$ concentrations were detected as a ratio image, using a dual filter wheel equipped with 340, 380 and $10 \mathrm{~nm}$ bandpass filters, and a range of neutral density filters (Photon Technology International, NJ, USA) every $3 \mathrm{~s}$ with a Cool One camera (Photon Technology International, Edison, NJ, USA). The data were acquired with Image Master software version 5.0 (Photon Technology International). The fluorescence ratio values were plotted vs time, and the AUC was calculated during the interval corresponding to the exposure to $11.1 \mathrm{mM}$ glucose.

\section{RNA extraction and quantitative polymerase chain reaction ( $q P C R$ )}

Analysis of mRNA expression was performed as previously described (16). Total RNA was extracted using Qiazol reagent from pools of 300 freshly isolated islets. Aliquots containing $2 \mu \mathrm{g}$ of RNA were subjected to RT using a highcapacity cDNA RT kit (Applied Biosystems). PCR reactions were conducted using QuantiNova SYBR Green PCR Kit (Qiagen) in a StepOnePlus Real-Time PCR System (Applied Biosystems).

The primer sequences were as follows: Gck sense: 5'-GCACAAGTCGTACCAGCT-3'; Gck antisense: 5'-AAA GCTCAGCGAACCCCG-3'; Slc2a2 sense: 5'-TCTTCA CGGCTGTCTCTG-3'; Slc2a2 antisense: 5'-GCACAGAAA AACATGCCA-3'; Kir6.2 sense: 5'-TGAGCGGTAGAG CACAAGC-3'; Kir6.2 antisense: 5'-TTTATACTACTAGCC TCA-3'; Sur1 sense: 5'-CAAGGTGTCCTCAACAACGG-3'; Sur1 antisense: 5'-CCAGGTGCTATGGTGAATGTG-3'; Cavb2 sense: 5'-CACTATTTCTCTGGCGTTCTGT-3'; Cavb2 antisense: 5'-CTGAGAAGACACCAACTGCCT-3; Cavb3 sense: 5'-CGCTAACCCGGTCTATGTCT-3'; Cavb3 antisense: 5'-GTGTAGGAGTCGGCTGAACC-3'; Rpl37a

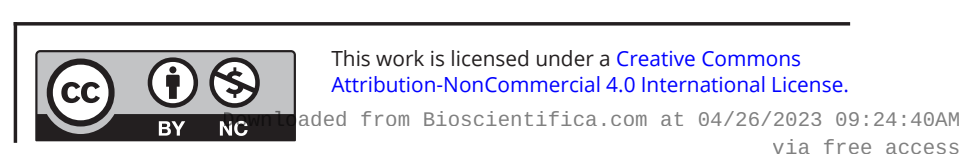


sense: 5'-CAAGAAGGTCGGGATCGTCG-3'; and Rpl37a antisense: 5'-ACCAGGCAAGTCTCAGGAGGTG-3'. The mRNA expression values were normalized using the geometric mean calculated from the internal control gene $R p l 37 a$. The fold changes were calculated via the $2-\Delta \Delta \mathrm{CT}$ method.

\section{Statistical analysis}

The results are presented as the mean \pm standard error of the mean (s.E.M.). Kolmogorov-Smirnov and ShapiroWilk normality tests were used to check for parametric distribution. Comparisons of parametric data were made with one-way ANOVA. Parametric insulin secretion data were compared using two-way ANOVA considering (i) glucose concentrations and (ii) experimental groups. Tukey's and Sidak's multiple comparisons test were applied when appropriate. Non-parametric data were compared with Kruskal-Wallis test followed by Dunn's multiple comparison test (GraphPad Prism Software, version 8.0, Inc.). $P$ values $<0.05$ indicated a significant difference.

\section{Results}

History of pregnancy followed by lactation improves maternal glucose tolerance later in life

Mice belonging to the virgin, L0 and L21 groups had similar body weights and daily food intake one day before the metabolic assays (Fig. 1A and B). The mice belonging to the different groups also had similar adiposity when evaluating either the inguinal or the retroperitoneal fat pads (Table 1). On the other hand, the AUC values obtained from GTT were reduced in L21 but not in L0 mice (16\% lower than in virgin mice; $P=0.01$ ) (Fig. $1 \mathrm{C}$ and $\mathrm{D})$. The increased glucose tolerance seen in L21 mice was not accompanied by changes in whole-body insulin sensitivity. Such affirmation is sustained by the similar $\mathrm{K}_{\mathrm{ITT}}$ values among the three groups (Fig. 1E and F).

\section{History of pregnancy followed by lactation} increases glucose-stimulated insulin secretion by maternal pancreatic islets later in life

Our data demonstrating that increased glucose tolerance in L21 mice was not paralleled by changes in peripheral insulin sensitivity was an indicative that mice allowed to breastfeed after delivery were able to exhibit a long-term increased in glucose-stimulated insulin secretion (GSIS) by pancreatic islets.
Attempting to clarify this issue, we evaluated GSIS by pancreatic islets isolated from virgin, L21 and L0 mice. Isolated pancreatic islets were incubated with glucose at a final concentration of either $5.6 \mathrm{mM}$ or $16.7 \mathrm{mM}$. Islets isolated from both virgin, L0 and L21 mice secreted more insulin when incubated with $16.7 \mathrm{mM}$ glucose (respectively 426, 1327 and 648\% higher than islets of the same group incubated with $5.6 \mathrm{mM}$ glucose; $P<0.001$ and $P<0.0001)$. However, insulin secretion stimulated by $16.7 \mathrm{mM}$ glucose was further elevated in islets of L21 mice (respectively 83 and 59\% higher than insulin secretion by islets of virgin and L0 mice incubated $16.7 \mathrm{mM}$ glucose; $P<0.001$ and $P<0.01$ ) (Fig. 2).
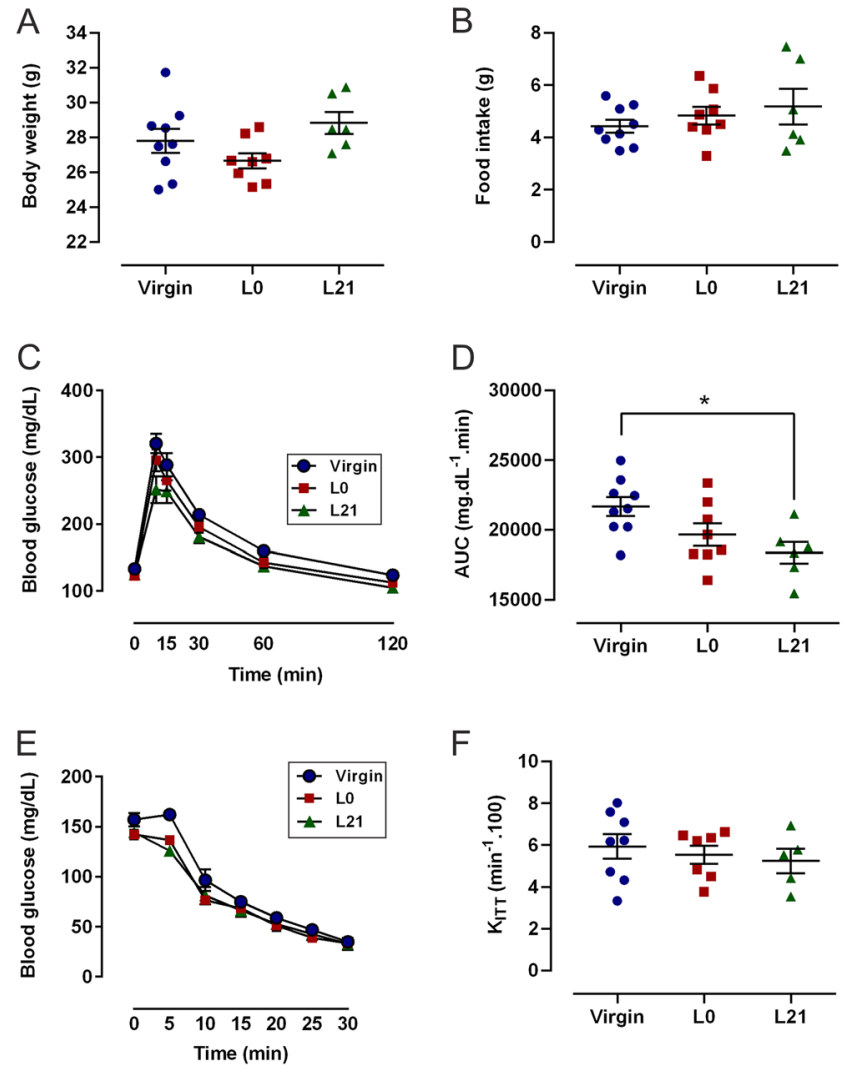

\section{Figure 1}

Glucose homeostasis in virgin, L0 and L21 mice. Body weight (A) and daily food intake (B) were recorded 3 months after the second delivery in LO and L21 mice. Simultaneous measurements were made in age-matched virgin mice (Virgin). Glucose tolerance tests were performed and the glycaemia vs time curves $(C)$ were used to calculate the area under the curve (AUC) (D). Insulin tolerance tests were performed and the glycaemia vs time curves (E) were used to calculate the $K_{I T}(F)$. Data are presented as the mean \pm S.E.M. Comparisons were made using one-way ANOVA. Virgin ( $n=9$ for body weight, food intake and GTT and $n=9$ for ITT), L0 ( $n=8$ for body weight, food intake and GTT and $n=7$ for ITT), L21 ( $n=6$ for body weight, food intake and GTT and $n=5$ for ITT). * $P=0.01$.

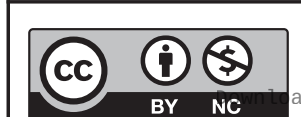

This work is licensed under a Creative Commons Attribution-NonCommercial 4.0 International License. ded from Bioscientifica.com at 04/26/2023 09:24:40AM via free access 


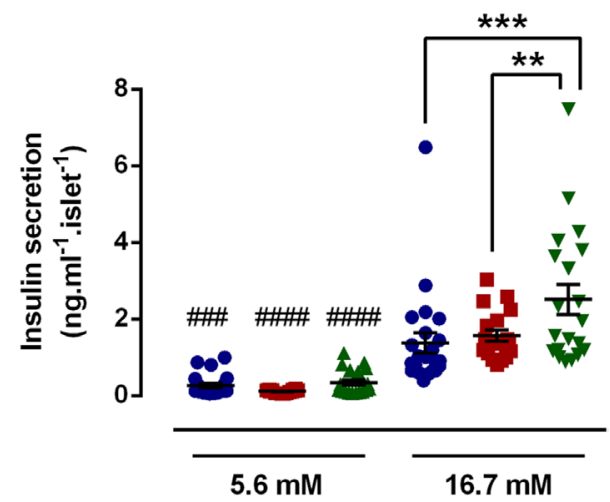

\section{Figure 2}

Insulin secretion by pancreatic islets isolated from Virgin, L0 and L21 mice. Pancreatic islets were isolated from L0 and L21 mice 3 months after the second delivery. Simultaneous isolations were made from agematched virgin mice (Virgin). Isolated islets were incubated with $5.6 \mathrm{mM}$ and $16.7 \mathrm{mM}$ glucose. After incubations, the supernatants were collected and used for insulin concentration determinations with commercially available ELISA kits. Data are presented as the mean \pm S.E.M. Comparisons were made using two-way ANOVA. Virgin $(n=23), \mathrm{L} 0(n=18), \mathrm{L} 21(n=20)$. $\# \# P<0.001$ and $\# \# \# P<0.0001$ vs islets from the same group incubated with $16.7 \mathrm{mM}$ glucose; $* * P<0.01$ and $* \star \star P<0.001$.

Increased insulin secretion by islets of mice with history of pregnancy followed by lactation is not associated with changes in macrophages infiltrated in adipose fat pads

Macrophages infiltrated in distinct adipose fat pads are recognized to produce several interleukins that are able to cause insulin resistance (17). Adipose tissue macrophages (ATM) can assume two distinct phenotypes, the M1-polarized macrophages ( $44 / 80^{+} /$ $\mathrm{CD} 11 \mathrm{c}^{+}$) and the M2-polarized macrophages $\left(\mathrm{F} 4 / 80^{+} /\right.$ $\mathrm{CD}^{206^{+}}$. The M1 macrophages, also known as pro-inflammatory macrophages, produce several interleukins such as tumor necrosis factor- $\alpha$ (TNF- $\alpha$ ) and interleukin-1 $\beta$ (IL-1 $\beta$ ) that induce insulin resistance in peripheral insulin-sensitive tissues (17). Importantly, accumulated evidence also indicates that these cytokines chronically impair pancreatic $\beta$-cell function $(18,19,20)$.

Aiming to elucidate if the increased insulin secretion capacity of pancreatic islets isolated of L21 mice would be due to changes in the pro-inflammatory status of the white adipose tissue, we evaluated the amount of $\mathrm{F} 4 / 80^{+} / \mathrm{CD} 11 \mathrm{c}^{+}$and $\mathrm{F} 4 / 80^{+} / \mathrm{CD}^{2} 26^{+}$cells in two distinct adipose fat pads. Our data demonstrate, however, similar percentages of $\mathrm{F} 4 / 80^{+} / \mathrm{CD} 11 \mathrm{c}^{+}$and $\mathrm{F} 4 / 80^{+} / \mathrm{CD} 206^{+}$ cells in both retroperitoneal and inguinal fat pads of virgin, L0 and L21 mice (Fig. 3B, C, D and E, respectively).
Pancreatic islets of mice with history of pregnancy followed by lactation do not exhibit long-lasting changes in pancreatic islet morphology

As our data have ruled out an extrinsic factor influencing insulin secretion in L21 mice, we decided to assess key morphological parameters that would impact pancreatic islet physiology. However, we found that mean pancreatic islet area, pancreatic islet $\beta$-cell area and pancreatic islet non- $\beta$-cell area were similar among L21, L0 and virgin mice (Fig. 4B, C and D, respectively). Representative images of pancreata sections are shown in Fig. 4A. The masses of pancreatic islet, pancreatic $\beta$-cell and pancreatic non- $\beta$-cell, and the number of islets per pancreas section were also similar among the different groups (Table 1).

\section{History of pregnancy followed by lactation leads to long-lasting changes in the expression of genes associated to pancreatic $\beta$-cell insulin secretion}

We next evaluated the expression of key genes that are pivotal for GSIS. The expression of Gck, Slc2a2 and Sur1 were equally expressed in islets of virgin, L0 and L21 mice (Fig. 5A, B and C, respectively). The expression of Kir6.2, however, was reduced in islets of L21 mice (36\% lower than in islets of L0 mice; $P=0.02$ ) (Fig. 5D). The genes codifying two different subunits of voltage-operated calcium channels, Cavb2 and Cavb3, were also evaluated. No changes were found in the expression of Cavb2 (Fig. $5 \mathrm{E})$, but the expression of Cavb3 was reduced in islets of L21 mice (respectively 30 and 28\% lower than in islets of virgin and L0 mice; $P<0.05$ ) (Fig. 5F).

\section{History of pregnancy followed by lactation} modifies the dynamics in intracellular calcium levels induced by glucose in pancreatic islets

In order to verify if the changes in genes expression detected in islets of L21 were generating relevant biological outcomes, we next assessed the dynamics in intracellular calcium in isolated pancreatic islets after stimulus with glucose. The analysis of the fluorescence ratio vs time spectra evidenced that the $16.7 \mathrm{mM}$ glucoseinduced increase of cytoplasmic calcium was upregulated in islets of L21 mice. This finding was evidenced by both the AUC (49\% higher than virgin and 66\% higher than L0; $P<0.05$ ) (Fig. 6D) and the maximal fluorescence amplitude (66\% higher than virgin and 59\% higher than 
A
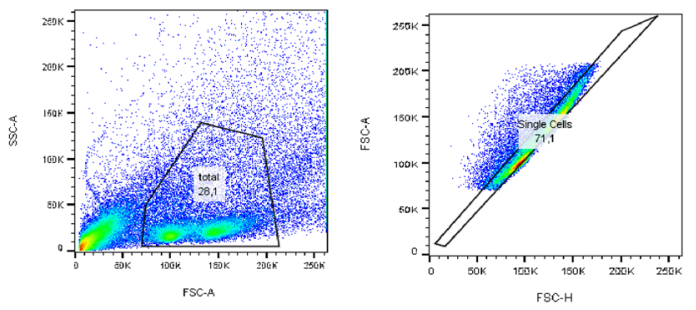

B

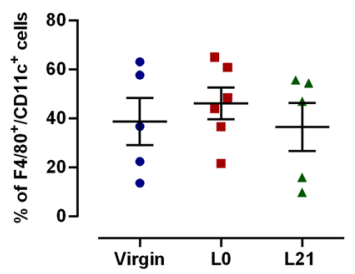

9:4

I

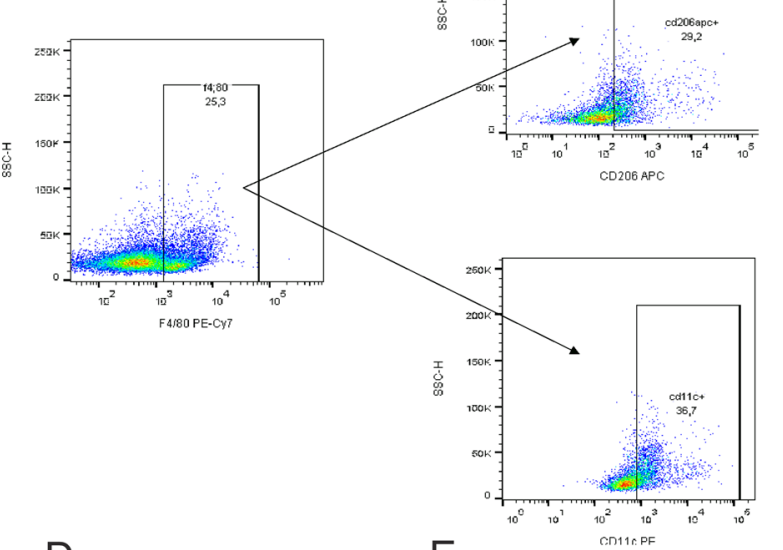

E

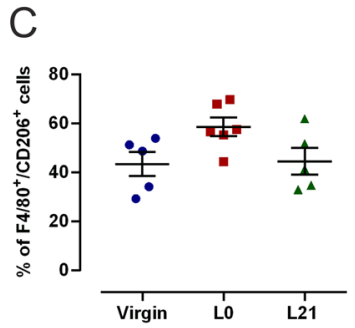

D

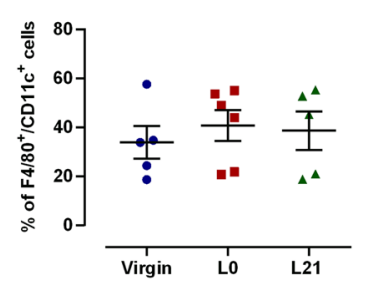

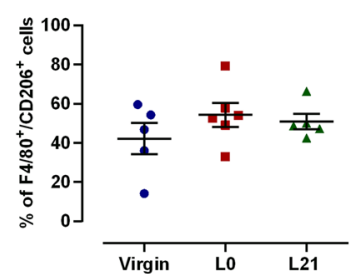

Figure 3

Macrophage infiltration in adipose tissues from virgin, L0 and L21 mice. Retroperitoneal and inguinal fat pads were isolated from L0 and L21 mice three months after the second delivery. Simultaneous isolations were made from age-matched virgin mice (virgin). Fat pads were digested and adipose tissue macrophages were processed for flow cytometry analyses. A gating strategy was adopted to identify F4/80 $/ \mathrm{CD} 11 \mathrm{C}^{+}$and $\mathrm{F} 4 / 80^{+} / \mathrm{CD} 206^{+}$macrophages (A). The number of $\mathrm{F} 4 / 80^{+} / \mathrm{CD} 11 \mathrm{C}^{+}(\mathrm{B})$ and $\mathrm{F} 4 / 80^{+} / \mathrm{CD} 206^{+}(\mathrm{C})$ macrophages in retroperitoneal fat pads and the $\mathrm{F} 4 / 80^{+} / \mathrm{CD} 11 \mathrm{C}^{+}(\mathrm{D})$ and $\mathrm{F} 4 / 80^{+} / \mathrm{CD} 206^{+}(\mathrm{E})$ in inguinal fat pads were expressed as the percentage of $\mathrm{F} 4 / 80^{+}$cells. Data are presented as the mean \pm S.E.M. Comparisons were made using one-way ANOVA. Virgin $(n=5)$, LO $(n=6)$, L21 $(n=5)$.

L0; $P<0.05$ and $P<0.01$, respectively) values (Fig. 6E). No changes in the number of calcium oscillations were found when comparing islets of virgin, L0 and L21 mice (Fig. 6F). Representative histograms showing changes in islet fluorescence vs time are shown in Fig. 6A, B and $\mathrm{C}$.

\section{Discussion}

Observational studies consistently show that the duration of the breastfeeding is inversely associated with the risk of mothers developing T2DM later in life $(6,7)$. In spite of these epidemiological evidence, no investigation had applied an experimental approach to detailed examine how lactation exerts a long-term modulation on maternal glucose homeostasis. To the best of our knowledge, the present data are the first to report that the long-term impacts of breastfeeding in glucose tolerance of mice are associated with sustained modulations of the maternal pancreatic islets physiology.
On the other hand, the present experiments with C57BL/6J mice demonstrated that repeated cycles of pregnancy with or without lactation do not interfere with maternal whole-body insulin sensitivity and pancreatic islet architecture later in life. Accordingly, we have also found that either pregnancy or pregnancy with lactation did not promote changes in M1 and M2 macrophages infiltration in maternal inguinal and retroperitoneal adipose tissue depots. Besides modulating peripheral insulin sensitivity through a mechanism dependent on pro-inflammatory cytokines (17), M1 and M2 infiltrated macrophages were also described to modulate adipocyte differentiation and adiposity (21). In general, central obesity resultant of increased visceral intra-abdominal adiposity is commonly associated to insulin resistance and increased risk for type 2 diabetes $(22,23)$. Recent human studies revealed, instead, that the amount of macrophages in s.c. adipose tissue correlates with visceral adiposity (24). Hence, our present data on unaltered M1 and M2 macrophages infiltration in both inguinal and retroperitoneal adipose tissue depots are also in

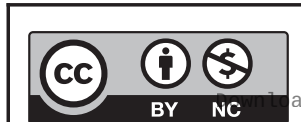

This work is licensed under a Creative Commons Attribution-NonCommercial 4.0 International License. ded from Bioscientifica.com at 04/26/2023 09:24:40AM via free access 

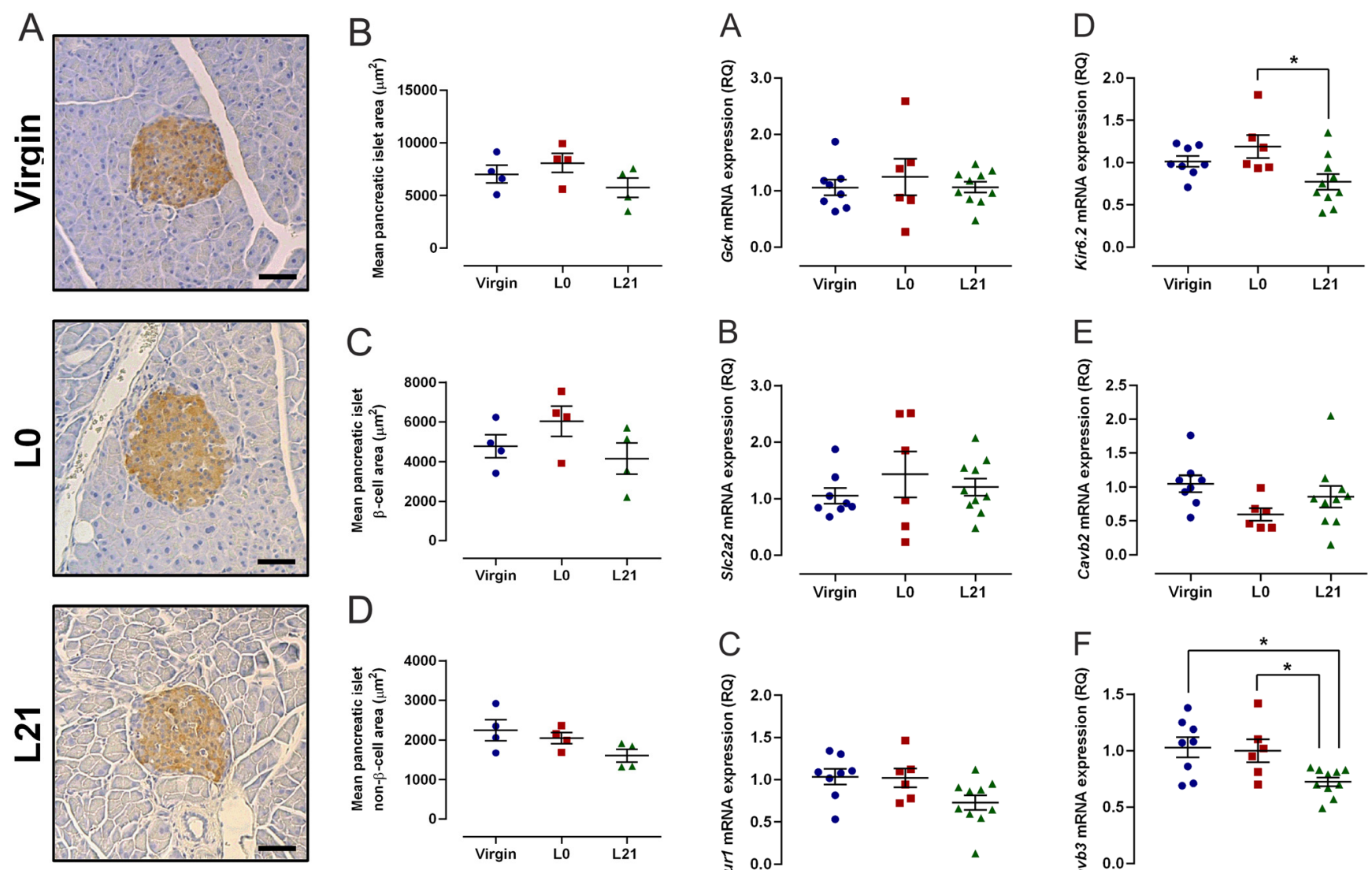

Figure 4

Morphological features of pancreatic islet from Virgin, L0 and L21 mice. Panels show paraplast-embedded pancreas sections ( $5 \mu \mathrm{m}$ thick) from age-matched virgins, and L0 and L21 (A) 3 months after the second delivery, which were immunolabelled for insulin. Bars: $50 \mu \mathrm{m}$. All islets were used for morphometric analysis of pancreatic islet area (B), pancreatic islet $\beta$-cell area (C) and pancreatic islet non- $\beta$-cell area (D). Data are presented as the mean \pm S.E.M. Comparisons were made using one-way ANOVA. Virgin $(n=4)$, LO $(n=4)$, L21 $(n=4)$.

accordance with our data demonstrating that the history of pregnancy with or without lactation does not modulate adiposity in C57BL/6J.

Important aspects differ the present data obtained in C57BL/6J mouse with those already published with women. Some important aspects, however, must be taken into account in order to explain such differences. Bajaj and colleagues have previously demonstrated that woman who had long periods of breastfeeding have increased insulin sensitivity and lower risk for pre-diabetes 3 years after delivery (8). The positive correlation between insulin sensitivity and breastfeeding duration seen in Bajaj's study was not accompanied by changes in Insulin Secretion Sensitivity Index-2 (ISSI-2) values (8). The ISSI-2 is a reliable index to assess the dynamics of in vivo insulin secretion during a glucose tolerance test (25). The current findings, instead, were based on in vitro assays to measure
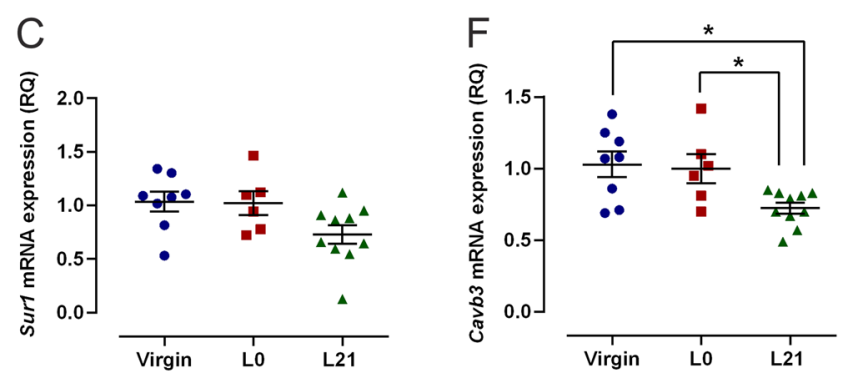

\section{Figure 5}

Gene expression in pancreatic islet from Virgin, L0 and L21 mice. Pancreatic islets were isolated from L0 and L21 mice 3 months after the second delivery. Simultaneous isolations were made from age-matched virgin mice (Virgin). Isolated islets were processed for mRNA quantification of Gck (A), Slc2a2 (B), Sur1 (C), Kir6.2 (D), Cavb2 (E) and Cavb3 (F). Data are presented as the mean \pm S.E.M. Comparisons were made using one-way ANOVA. Virgin $(n=8)$, L0 $(n=6)$, L21 $(n=10) .{ }^{*} P<0.05$.

insulin secretion from mouse isolated pancreatic islets. In this in vitro context, islets isolated from mice allowed to lactate secreted more insulin in response to glucose than those isolated from mice not allowed to lactate.

It is noteworthy that signals other than glucose act as primary stimulators of insulin secretion in vivo. Such signals can be both neurotransmitters released during the cephalic phase of insulin release or incretins such as glucagon-like peptide 1 (GLP-1) and gastric inhibitory peptide (GIP) released by enteroendocrine cells in response to food transit (26). Human islets are particularly sensitive to GLP-1 and GIP effect on insulin secretion (27). Such features of human islets may serve to explain the greater insulin secretion in response to oral glucose when compared to i.v. glucose (26). Hence, the influence of these enteroendocrine signals on in vivo insulin secretion 

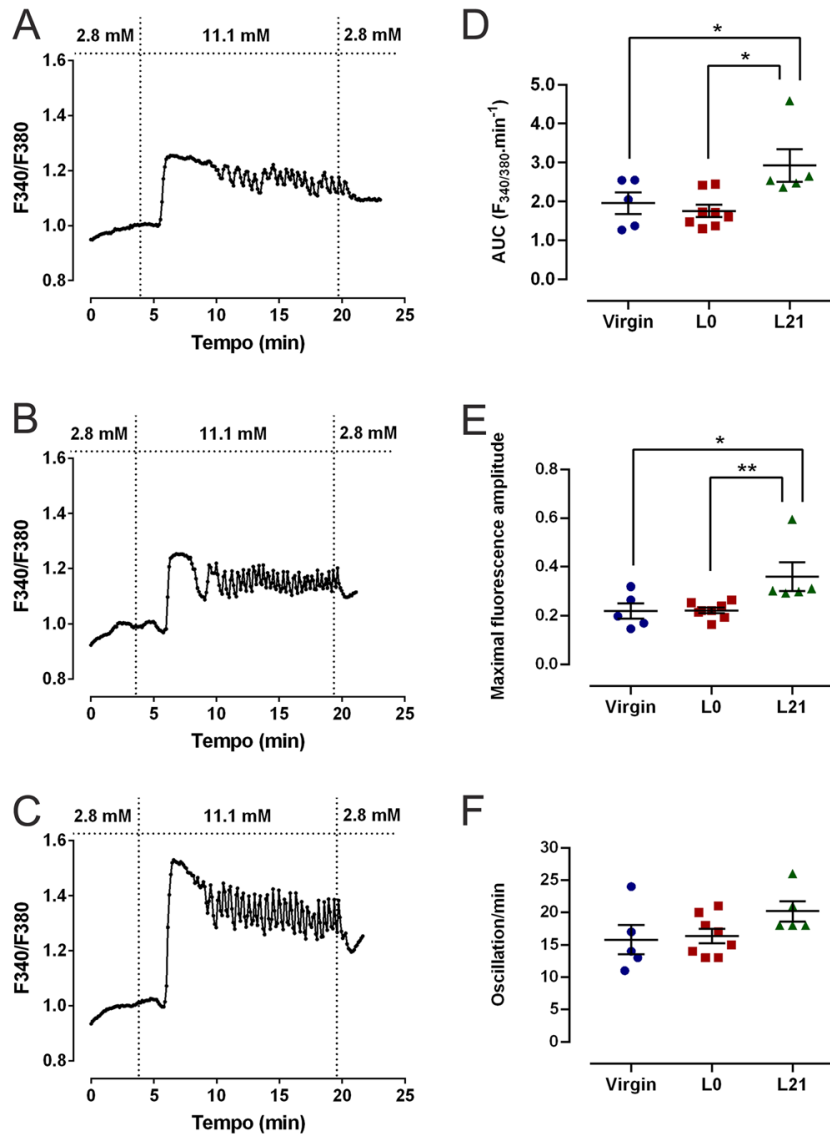

\section{Figure 6}

Intracellular calcium dynamics in pancreatic islet from Virgin, L0 and L21 mice. Pancreatic islets were isolated from L0 and L21 mice 3 months after the second delivery. Simultaneous isolations were made from agematched virgin mice (Virgin). Representative curves of $11.1 \mathrm{mM}$ glucoseinduced intracellular $\mathrm{Ca}^{2+}$ oscillations in islets from Virgin (A), LO (B) and L21 (C). The AUC (D), the maximal fluorescence amplitude (E) and the frequency of oscillations (F) were calculated within the interval of exposure to $11.1 \mathrm{mM}$ glucose. The experiments were performed in a perfusion system in a medium that contained $2.8 \mathrm{mM}$ or $11.1 \mathrm{mM}$ glucose. Data are presented as the mean \pm S.E.M. AUC and maximal fluorescence amplitude were compared with Kruskal-Wallis test and numbers of oscillations per minute were compared with one-way ANOVA. Virgin $(n=5)$, L0 $(n=8)$, L21 $(n=5) . * P<0.05$ and $* * P<0.01$.

may overcome those arising from breastfeeding period in women. Such influences might be absent when insulin secretion is measured from isolated pancreatic islets stimulated with glucose.

With the attempt to clarify the mechanism for increased GSIS in L21 islets, we investigated the expression of pivotal genes for insulin secretion. Our data revealed that the expression of the genes the codify Glut2 and glucokinase, two main glucose sensors of the pancreatic $\beta$-cell, were not differentially expressed in islets of mice subjected to cycles of pregnancy followed by lactation. Similarly, no modulations were found in the expression of Sur1, the gene that codifies the ATP-sensitive regulatory subunit of the $\mathrm{K}_{\text {ATP }}$ channel that couples glucose metabolism to $\beta$-cell depolarization. Interestingly, our experiments revealed that the expression of Kir6.2, the pore forming subunit of $\mathrm{K}_{\mathrm{ATP}}$, was reduced in islets of mice allowed to lactate after delivery.

The phenotype of the mice expressing a dominantnegative form of Kir6.2 in the pancreatic $\beta$-cell changes through the course of its life. These mice have hypoglycemia with hyperinsulinemia during neonatal life with higher basal intracellular calcium in pancreatic $\beta$-cells. The permanent increase in intracellular calcium, however, increases the apoptosis and decreases pancreatic $\beta$-cell mass during adulthood, leading these transgenic mice to a switch to a hyperglycemic phenotype later in life (28). This complex and dynamic phenotype limits the parallels that can be traced between the mice that completely lack Kir6.2 in the $\beta$-cells and the mice belonging to the L21 group of the present study.

In our view, more appropriate is the interpretation of the results obtained with islets of L21 mice taking into account data previously reported with the transgenic AAA-TG line of mice. The AAA-TG mice have approximately $70 \%$ of pancreatic $\beta$-cells with nonfunctional Kir6.2. These $\beta$-cells showed absent hyperpolarizing $\mathrm{K}_{\mathrm{ATP}}$ current and increased intracellular calcium levels and GSIS (29). In vivo, AAA-TG mice demonstrated improved glucose tolerance as they reached the age of 24 months (30). Interestingly, transcriptome analysis revealed that treatment with toxic concentrations of saturated fatty acids is able to increase Kir6.2 expression in human pancreatic islets (31).

Another relevant finding in islets of mice belonging to the L21 group was the reduction in the expression of the Cavb3. While $\alpha_{1}$ subunits of the voltage-gated $\mathrm{L} \mathrm{Ca}^{2+}$ channel form the pore, the $\beta$ subunits modulate $\mathrm{Ca}^{2+}$ currents (26). Mice knockout for Cavb3, the gene that encodes the $\beta_{3}$ subunit of the voltage-gated $\mathrm{L} \mathrm{Ca}^{2+}$ channel, have increased glucose tolerance and higher GSIS by isolated islets (30). Islets of mice knockout for Cavb3 also presented a higher frequency and increased maximal amplitude in intracellular $\mathrm{Ca}^{2+}$ oscillation induced by glucose $(30,32)$.

Hence, our data indicating increased maximal amplitude of intracellular calcium and increased calcium concentration in L21 pancreatic islets incubated with stimulatory concentration of glucose points to a functional role of reduced Cavb3 and Kir6.2 for the long-lasting increased insulin secretion seen in this group of mice.

The endocrine and neuronal changes that occur in a lactating dam are complex and several factors can possibly

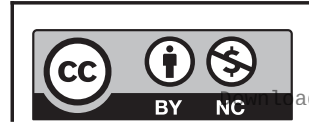

This work is licensed under a Creative Commons Attribution-NonCommercial 4.0 International License. ded from Bioscientifica.com at 04/26/2023 09:24:40AM 
exert long-term effects on pancreatic islets. It is reasonable to point, however, to a putative role of the frequent bursts in pituitary prolactin (PRL) production presumably experienced by L21, but not by L0 and Virgin mice. Although both pregnant and lactating mice are known to have high levels of PRL, the production of this hormone during lactation is highly dependent on the suckling stimulus (33). PRL, in turns, is classically recognized to exert positive effects over insulin secretion. PRL-knockout mice display reduced insulin secretion during pregnancy and PRL per se increases GSIS in vitro $(34,35)$.

One limitation of our study is that although the present experiments clearly demonstrate that breastfeeding yields long-term benefits for the maternal endocrine pancreas of mice, we cannot assure that such changes also occur in women. Much more studies with isolated human islets are necessary to establish if the changes found in mice are replicated in women. Thus, it still premature to affirm that breastfeeding itself would exert long-term effect on human islet insulin secretion and calcium handling.

In conclusion, our results demonstrate that mice subjected to sequential cycles of pregnancy and lactation exhibits long-term improvement of glucose tolerance that is linked to increased GSIS. Conciliatory and long-lasting changes in Cavb3 and Kir6.2 expression and changes in calcium dynamics were found to explain such changes. No similar modulations were found in mice not allowed to breastfeed after delivery. Altogether, the present findings show that the sustained benefits elicited by breastfeeding for maternal glucose homeostasis in mice are mediated by changes in pancreatic $\beta$-cells. These results might serve to comprehend the mechanism related to the inverse relationship between breastfeeding duration and maternal risk for T2DM later in life.

\section{Declaration of interest}

The authors declare that there is no conflict of interest that could be perceived as prejudicing the impartiality of the research reported.

\section{Funding}

This study was funded by Fundação de Amparo à Pesquisa do Estado de São Paulo (FAPESP Grants 2013/07607-8 and 2015/12680-1 and scholarship 2017/11138-4), Conselho Nacional de Desenvolvimento Científico e Tecnológico (CNPq) and Coordenação de Aperfeiçoamento de Pessoal de Nível Superior (CAPES - Finance Code 001).

\section{Ethics approval}

The present experiments were conducted in accordance with the guidelines of the Brazilian College for Animal Experimentation after the authorization of the State University of Campinas Committee for Ethics in Animal Experimentation (protocols No. 4496-1, No. 3711-1 and No. 4863-1).

\section{Author contribution statement}

G F A and J M V designed the research. J M V, J C S-S, C J T, D N de S, J F V, F S F, I G A, F T S and M A R V performed the experiments and analyzed the data. E M C, M A R V, S B and G F A contributed to the discussions. G F A and $S$ B wrote the paper.

\section{Acknowledgements}

The authors are grateful to Miguel Borges da Silva, Agnaldo Fernando de Azevedo and Ivani Franco Correia dos Santos for the technical assistance.

\section{References}

1 Davis WH. Prevention of infant mortality by breast feeding. American Journal of Public Health 19122 67-71. (https://doi.org/10.2105/ ajph.2.2.67-a)

2 Stuebe A. The risks of not breastfeeding for mothers and infants. Reviews in Obstetrics and Gynecology 20092 222-231. (https://doi. org/10.3909/riog0093)

3 Horta BL \& de Lima NP. Breastfeeding and Type 2 diabetes: systematic review and meta-analysis. Current Diabetes Reports 201919 1. (https://doi.org/10.1007/s11892-019-1121-x)

4 Horta BL, Loret de Mola C \& Victora CG. Long-term consequences of breastfeeding on cholesterol, obesity, systolic blood pressure and type 2 diabetes: a systematic review and meta-analysis. Acta Paediatrica 2015 104 30-37. (https://doi.org/10.1111/apa.13133)

5 Wang J, Perona JS, Schmidt-RioValle J, Chen Y, Jing J \& GonzálezJiménez E. Metabolic syndrome and its associated early-life factors among Chinese and Spanish adolescents: a pilot study. Nutrients 201911 1568. (https://doi.org/10.3390/nu11071568)

6 Schwarz EB, Ray RM, Stuebe AM, Allison MA, Ness RB, Freiberg MS $\&$ Cauley JA. Duration of lactation and risk factors for maternal cardiovascular disease. Obstetrics and Gynecology 2009113 974-982. (https://doi.org/10.1097/01.AOG.0000346884.67796.ca)

7 Stuebe AM, Rich-Edwards JW, Willett WC, Manson JE \& Michels KB. Duration of lactation and incidence of type 2 diabetes. JAMA 2005 294 2601-2610. (https://doi.org/10.1001/jama.294.20.2601)

8 Bajaj H, Ye C, Hanley AJ, Connelly PW, Sermer M, Zinman B \& Retnakaran R. Prior lactation reduces future diabetic risk through sustained postweaning effects on insulin sensitivity. American Journal of Physiology: Endocrinology and Metabolism 2017312 E215-E223. (https://doi.org/10.1152/ajpendo.00403.2016)

9 Bytautiene Prewit E, Kechichian T, Okunade D, Yin H \& Stuebe AM. Effect of normal pregnancy followed by lactation on long-term maternal health in a mouse model. Reproductive Sciences 201825 1186-1196. (https://doi.org/10.1177/1933719117734316)

10 Zhong S, Almario R, Dubrinsky M, Rose K, Lin PK, Grunberger G \& Jen KL. Repeated pregnancy without lactation: effects on maternal glycemic control, pregnancy outcome, carcass composition, and fat distribution in rats. Metabolism: Clinical and Experimental 199039 1127-1132. (https://doi.org/10.1016/0026-0495(90)90083-o)

11 Vicente JM, Teixeira CJ, Santos-Silva JC, de Souza DN, Tobar N, Furtuoso FS, Adabo IG, Sodré FS, Murata G, Bordin S, et al. The absence of lactation after pregnancy induces long-term lipid accumulation in maternal liver of mice. Life Sciences $20192 \mathbf{2 1 7}$ 261-270. (https://doi.org/10.1016/j.lfs.2018.12.026)

12 Bromati CR, Lellis-Santos C, Yamanaka TS, Nogueira TC, Leonelli M, Caperuto LC, Gorjão R, Leite AR, Anhê GF \& Bordin S. UPR induces transient burst of apoptosis in islets of early lactating rats through reduced AKT phosphorylation via ATF4/CHOP stimulation of TRB3 expression. American Journal of Physiology: Regulatory, Integrative and Comparative Physiology 2011300 R92-R100. (https://doi.org/10.1152/ ajpregu.00169.2010) https://ec.bioscientifica.com

https://doi.org/10.1530/EC-20-0020 (c) 2020 The authors Published by Bioscientifica Ltd

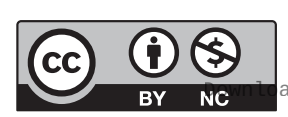

This work is licensed under a Creative Commons Attribution-NonCommercial 4.0 International License. ded from Bioscientifica.com at 04/26/2023 09:24:40AM 
13 Teixeira CJ, Santos-Silva JC, de Souza DN, Rafacho A, Anhe GF $\&$ Bordin S. Dexamethasone during pregnancy impairs maternal pancreatic beta-cell renewal during lactation. Endocrine Connections 20198 120-131. (https://doi.org/10.1530/EC-18-0505)

14 Santos-Silva JC, Ribeiro RA, Vettorazzi JF, Irles E, Rickli S, Borck PC, Porciuncula PM, Quesada I, Nadal A, Boschero AC, et al. Taurine supplementation ameliorates glucose homeostasis, prevents insulin and glucagon hypersecretion, and controls beta, alpha, and deltacell masses in genetic obese mice. Amino Acids 201547 1533-1548. (https://doi.org/10.1007/s00726-015-1988-z)

15 de Almeida Faria J, de Araújo TM, Mancuso RI, Meulman J, da Silva Ferreira D, Batista TM, Vettorazzi JF, da Silva PM, Rodrigues SC, Kinote A, et al. Day-restricted feeding during pregnancy and lactation programs glucose intolerance and impaired insulin secretion in male rat offspring. Acta Physiologica 2016217 240-253. (https://doi. org/10.1111/apha.12684)

16 Lellis-Santos C, Sakamoto LH, Bromati CR, Nogueira TC, Leite AR, Yamanaka TS, Kinote A, Anhê GF \& Bordin S. The regulation of Rasd1 expression by glucocorticoids and prolactin controls peripartum maternal insulin secretion. Endocrinology 2012153 3668-3678. (https://doi.org/10.1210/en.2012-1135)

17 McNelis JC \& Olefsky JM. Macrophages, immunity, and metabolic disease. Immunity 201441 36-48. (https://doi.org/10.1016/j. immuni.2014.05.010)

18 Dickerson MT, Bogart AM, Altman MK, Milian SC, Jordan KL, Dadi PK \& Jacobson DA. Cytokine-mediated changes in $\mathrm{K}(+)$ channel activity promotes an adaptive $\mathrm{Ca}(2+)$ response that sustains beta-cell insulin secretion during inflammation. Scientific Reports $2018 \mathbf{8} 1158$ (https://doi.org/10.1038/s41598-018-19600-x)

19 Dula SB, Jecmenica M, Wu R, Jahanshahi P, Verrilli GM, Carter JD, Brayman KL \& Nunemaker CS. Evidence that low-grade systemic inflammation can induce islet dysfunction as measured by impaired calcium handling. Cell Calcium 201048 133-142. (https://doi. org/10.1016/j.ceca.2010.07.007)

20 Qureshi FM, Dejene EA, Corbin KL \& Nunemaker CS. Stress-induced dissociations between intracellular calcium signaling and insulin secretion in pancreatic islets. Cell Calcium 201557 366-375. (https:// doi.org/10.1016/j.ceca.2015.03.002)

21 Chazenbalk G, Bertolotto C, Heneidi S, Jumabay M, Trivax B, Aronowitz J, Yoshimura K, Simmons CF, Dumesic DA \& Azziz R. Novel pathway of adipogenesis through cross-talk between adipose tissue macrophages, adipose stem cells and adipocytes: evidence of cell plasticity. PLOS ONE 20116 e17834. (https://doi.org/10.1371/ journal.pone.0017834)

22 Nicklas BJ, Cesari M, Penninx BW, Kritchevsky SB, Ding J, Newman A, Kitzman DW, Kanaya AM, Pahor M \& Harris TB. Abdominal obesity is an independent risk factor for chronic heart failure in older people. Journal of the American Geriatrics Society 200654 413-420. (https://doi.org/10.1111/j.15325415.2005.00624.x

23 Wang Y, Rimm EB, Stampfer MJ, Willett WC \& Hu FB. Comparison of abdominal adiposity and overall obesity in predicting risk of type
2 diabetes among men. American Journal of Clinical Nutrition $2005 \mathbf{8 1}$ 555-563. (https://doi.org/10.1093/ajcn/81.3.555)

24 Kursawe R, Dixit VD, Scherer PE, Santoro N, Narayan D, Gordillo R, Giannini C, Lopez X, Pierpont B, Nouws J, et al. A role of the inflammasome in the low storage capacity of the abdominal subcutaneous adipose tissue in obese adolescents. Diabetes $2016 \mathbf{6 5}$ 610-618. (https://doi.org/10.2337/db15-1478)

25 Retnakaran R, Shen S, Hanley AJ, Vuksan V, Hamilton JK \& Zinman B. Hyperbolic relationship between insulin secretion and sensitivity on oral glucose tolerance test. Obesity 200816 1901-1907. (https://doi.org/10.1038/oby.2008.307)

26 Rorsman P \& Ashcroft FM. Pancreatic beta-cell electrical activity and insulin secretion: of mice and men. Physiological Reviews 201898 117-214. (https://doi.org/10.1152/physrev.00008.2017)

27 Rutter GA \& Hodson DJ. Minireview: intraislet regulation of insulin secretion in humans. Molecular Endocrinology 201327 1984-1995. (https://doi.org/10.1210/me.2013-1278)

28 Miki T, Tashiro F, Iwanaga T, Nagashima K, Yoshitomi H, Aihara H, Nitta Y, Gonoi T, Inagaki N, Miyazaki Ji, et al. Abnormalities of pancreatic islets by targeted expression of a dominant-negative KATP channel. PNAS 199794 11969-11973. (https://doi.org/10.1073/ pnas.94.22.11969)

29 Koster JC, Remedi MS, Flagg TP, Johnson JD, Markova KP, Marshall BA \& Nichols CG. Hyperinsulinism induced by targeted suppression of beta cell KATP channels. PNAS 200299 16992-16997. (https://doi.org/10.1073/pnas.012479199)

30 Berggren PO, Yang SN, Murakami M, Efanov AM, Uhles S, Köhler M, Moede T, Fernström A, Appelskog IB, Aspinwall CA, et al. Removal of $\mathrm{Ca} 2+$ channel beta3 subunit enhances $\mathrm{Ca} 2+$ oscillation frequency and insulin exocytosis. Cell 2004119 273-284. (https://doi. org/10.1016/j.cell.2004.09.033)

31 Cnop M, Abdulkarim B, Bottu G, Cunha DA, Igoillo-Esteve M, Masini M, Turatsinze JV, Griebel T, Villate O, Santin I, et al. RNA sequencing identifies dysregulation of the human pancreatic islet transcriptome by the saturated fatty acid palmitate. Diabetes $20146 \mathbf{6 3}$ 1978-1993. (https://doi.org/10.2337/db13-1383)

32 Lee K, Kim J, Köhler M, Yu J, Shi Y, Yang SN, Ryu SH \& Berggren PO. Blocking $\mathrm{Ca}(2+)$ channel beta3 subunit reverses diabetes. Cell Reports 201824 922-934. (https://doi.org/10.1016/j.celrep.2018.06.086)

33 Yanai R \& Nagasawa H. Pituitary prolactin and growth hormone levels during different reproductive states in mice with a high or a low lactational performance. Hormones and Behavior 19712 73-82. (https://doi.org/10.1016/0018-506X(71)90040-7)

34 Huang C, Snider F \& Cross JC. Prolactin receptor is required for normal glucose homeostasis and modulation of beta-cell mass during pregnancy. Endocrinology 2009150 1618-1626. (https://doi. org/10.1210/en.2008-1003)

35 Amaral ME, Ueno M, Carvalheira JB, Carneiro EM, Velloso LA, Saad MJ \& Boschero AC. Prolactin-signal transduction in neonatal rat pancreatic islets and interaction with the insulin-signaling pathway. Hormone and Metabolic Research 200335 282-289. (https://doi. org/10.1055/s-2003-41303)

Received in final form 17 February 2020

Accepted 17 March 2020

Accepted Manuscript published online 17 March 2020 https://ec.bioscientifica.com https://doi.org/10.1530/EC-20-0020 (c) 2020 The authors Published by Bioscientifica Ltd

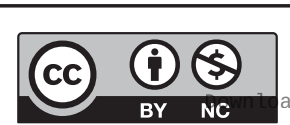

This work is licensed under a Creative Commons Attribution-NonCommercial 4.0 International License. ded from Bioscientifica,com at 04/26/2023 09:24:40AM 